\title{
Severity of clubroot in kale related to management practices and soil attributes
}

\author{
Carlos Antônio dos Santos ${ }^{1^{*}(1)}$ Nelson Moura Brasil do Amaral Sobrinho ${ }^{2}$ (1) \\ Erica Souto Abreu Lima ${ }^{2}$ (i) Margarida Goréte Ferreira do Carmo ${ }^{1}$ (])
}

${ }^{1}$ Departamento de Fitotecnia, Instituto de Agronomia (IA), Universidade Federal Rural do Rio de Janeiro (UFRRJ), 23897-000, Seropédica, RJ, Brasil. E-mail: carlosantoniokds@gmail.com. "Corresponding author.

${ }^{2}$ Departamento de Solos, Instituto de Agronomia (IA), Universidade Federal Rural do Rio de Janeiro (UFRRJ), Seropédica, RJ, Brasil.

ABSTRACT: Clubroot disease, caused by Plasmodiophora brassicae, limits the production of Brassica spp. worldwide. Little is known about the factors related to the development of the disease in kale (Brassica oleracea var. acephala) plants and in crops in mountainous areas under tropical conditions. This study examined the severity of clubroot in kale crops as well as identify potential flaws in management and the soil and relief factors related to its occurrence. The study was conducted in 24 kale fields in the mountainous region of Rio de Janeiro (Brazil). Soil and kale growth management practices adopted in the region were identified and samples of soil and plants were collected. Subsequently, soil and relief attributes, disease severity, biomass and nutrient and Al contents and accumulation in the plants were determined. There was a high spread of the pathogen in the areas. Inappropriate and recurrent practices in the region were detected, e.g., sequential cultivation of host species, low adoption of soil fertility analysis and liming and conservation practices, and community use of agricultural machinery and implements without prior cleaning. The disease was associated with more acidic soils, subject to greater water accumulation and with high levels of $\mathrm{Al}^{3+}$ as well as with higher Al contents and accumulation in the roots. Management practices must be adopted in the region to reduce the potential inoculum of $P$. brassicae and to increase soil fertility.

Key words: Brassica oleracea var. acephala, Plasmodiophora brassicae, mountain agriculture, acidity, aluminum.

Severidade da hérnia das crucíferas em couve-comum relacionada

a práticas de manejo e atributos do solo

RESUMO: A hérnia das cruciferas, causada por Plasmodiophora brassicae, é limitante à produção de Brassica spp. em todo o mundo. Pouco se conhece sobre os fatores relacionados ao desenvolvimento da doença em plantas de couve-comum (Brassica oleracea var. acephala) e em cultivos em áreas de montanha sob condições tropicais. Objetivou-se avaliar a severidade da hérnia das cruciferas em lavouras de couvecomum, identificar potenciais falhas no manejo e os fatores de solo e relevo relacionados a sua ocorrência. $O$ estudo foi conduzido em 24 lavouras de couve-comum da Região Serrana do Rio de Janeiro (Brasil). Registraram-se as práticas de manejo do solo e da couve-comum adotadas na região e coletaram-se amostras de solo e plantas. Em seguida, determinaram-se os atributos do solo e do relevo, a severidade da doença, biomassa e os teores e acúmulo de nutrientes e Al nas plantas. Observou-se alta disseminação do patógeno nas áreas. Foram identificadas práticas inadequadas e recorrentes na região como o cultivo sequencial de espécies hospedeiras, baixa adoção a análise de fertilidade, calagem e de medidas de conservação do solo, e o uso comunitário de máquinas e implementos agricolas sem limpeza prévia. Identificou-se associação da doença com solos mais ácidos, sujeitos a maior acúmulo de água e com elevados teores de Al ${ }^{3+}$; e a maior teor e acúmulo de Al nas raízes. Práticas de manejo devem ser adotadas na região visando a redução do potencial de inóculo de P. brassicae e o aumento da fertilidade do solo.

Palavras-chave: Brassica oleracea var. acephala, Plasmodiophora brassicae, agricultura de montanha, acidez, alumínio.

\section{INTRODUCTION}

Kale (Brassica oleracea L. var. acephala) is a leafy vegetable with great nutritional and medicinal value that is highly appreciated in Brazilian and worldwide cuisine (TRANI et al., 2015; SAMEC et al., 2019). This plant is predominantly propagated by shoots from axillary buds and has multiple harvests and a cultivation cycle that can extend over periods of more than one year (TRANI et al., 2015). Like other vegetables of the species $B$. oleracea, kale is better produced under mild temperatures, which is why it is commonly grown in higher-altitude regions in Brazil (TRANI et al., 2015; BHERING et al., 2017; SANTOS et al., 2020; SANTOS et al., 2021).

The cultivation of kale and other brassicas is affected worldwide by the clubroot disease, which is caused by the protozoan Plasmodiophora brassicae 
Woronin, a biotrophic phytopathogen specific to species of the family Brassicaceae. This pathogen infects and colonizes the roots, resulting in the formation of galls and impairing water and nutrient absorption process (DIXON, 2009; GOSSEN et al., 2014; BOTERO et al., 2019). As a consequence, plant development and production are compromised. Depending on local conditions, productivity losses can vary from 10 to $50 \%$ (DIXON, 2009).

Although, the first report of clubroot in Brazil occurred in the kale crop in 1934, in São Paulo (VIÉGAS \& TEIXEIRA, 1943), there is still little research on the disease in the country (HASSE et al., 2007; RUARO et al., 2010; KOWATADRESCH \& MAY-DE MIO, 2012; BHERING et al., 2017; SANTOS et al., 2017; BHERING et al., 2020; SANTOS et al., 2020), especially in kale. Most of the information about the disease and proposed management strategies are based on studies carried out in temperate regions, mainly in the canola, Chinese cabbage, cauliflower and broccoli crops (WEBSTER \& DIXON, 1991; NIWA et al., 2008; DIXON, 2009; GOSSEN et al., 2014). These differ from kale in various aspects, e.g., organ of interest, management and cycle length.

Clubroot is a complex and difficult-tocontrol disease. Plasmodiophora brassicae survives in the soil as resting spores, and options for resistant cultivars and active ingredients for chemical control are extremely restricted worldwide (DIXON, 2009; KOWATA-DRESCH \& MAY-DE MIO, 2012; DONALD \& PORTER, 2009; SANTOS et al., 2020; SANTOS et al., 2021). The intensity of the disease is affected by the chemical, physical and biological characteristics of the soil (DIXON, 2009; DONALD \& PORTER, 2009; BHERING et al., 2017; BHERING et al., 2020). Low $\mathrm{pH}$ values $(<6.2)$ and $\mathrm{Ca}^{2+}$ levels are among the factors that most contribute to the root infection and colonization process (WEBSTER \& DIXON, 1991; NIWA et al., 2008; DIXON, 2009; RUARO et al., 2010; GOSSEN et al., 2014; SANTOS et al., 2017; SANTOS et al., 2020).

In tropical and mountainous regions, the losses caused by clubroot can be aggravated by unique soil-climatic characteristics, such as high slope; weathered, naturally acidic soils or soils with high levels of $\mathrm{Al}^{3+}$; high temperatures and precipitation; besides the possibility of growing Brassica all year round (HASSE et al., 2007; RUARO et al., 2010; BHERING et al., 2017; SANTOS et al., 2017; BOTERO et al., 2019; SANTOS et al., 2020).

Given the singularities of the species $B$. oleracea var. acephala and the little information about clubroot in mountain agroecosystems in tropical conditions, the present study was developed with the aim of: 1) quantifying the severity of clubroot in kale crops; 2) identifying potential flaws in management that contribute to the development of the disease; and 3) identifying soil and relief factors that most affect the occurrence of the disease in the region.

\section{MATERIALS AND METHODS}

Study area

The survey was conducted in 24 kale fields located in the municipality of Petrópolis, in the mountainous region of Rio de Janeiro, Brazil. The region, which has a history of brassica growing for over 30 years, has a high slope, high level of inoculum of $P$. brassicae in the soil (average of $10^{6}$ units $\mathrm{g} \mathrm{soil}^{-1}$ ) (SANTOS et al., 2020), as well as reports of frequent occurrence of clubroot and consequent losses. Planting is achieved through the vegetative propagation of local clones, which had been cultivated for more than 20 years, observing the standard spacing of $0.5 \mathrm{~m} \times 0.3 \mathrm{~m}$.

The study occurred during the first half of February 2017. The summer period in this region is characterized by higher temperatures and high precipitation, when compared with other periods of the year. Data records from the National Meteorological Institute of Brazil (INMET) for the region revealed temperatures from 7.8 to $27.5^{\circ} \mathrm{C}$, an average temperature of $17.4{ }^{\circ} \mathrm{C}$, and accumulated precipitation of $580 \mathrm{~mm}$ in the last two months preceding the collections.

Survey of management practices adopted in the kale crops

A survey was initially conducted on the history of use of the areas and the management adopted in each of the 24 studied fields. The following data were recorded: crops prior to kale; type of soil preparation; origin of machines and implements and information on their prior cleaning; analysis of soil fertility; history of acidity correction and fertilization; planting date of the kale; management practices adopted in the crop; disease occurrence records; and management of crop residues. The obtained data were tabulated, response variations were identified and the percentages in relation to the total samples were calculated using SigmaPlot ${ }^{\circledR}$ software version 12.

Sampling, evaluation and processing of kale and soil samples

Soil and plant samples were collected from these same areas at random, at the rate of one sample 
(soil + plant) for every 1000 individuals, which totaled 146 points sampled across the study region. These points were chosen at random and considering a zigzag walk from the highest to the lowest point in each area. The sampled plants had characteristics compatible with those of the population in the area. Each collection point was georeferenced using a topographic GPS (Garmin, Montana TM 650 model) and the coordinates measured in UTM (Universal Transverse Mercator) (Figure 1).

One plant was collected from each sampling point by cutting at the base of the stem, followed by labeling and packaging. Then, the soil block with the roots corresponding to the plant were collected using a straight shovel. Once the block was removed, they were transported to the laboratory, where the roots and soil were separated and the shoots were processed.

In the plant samples, the fresh weight of stem and leaves, the number of leaves and leaf scars on the stem were determined. The roots were washed and then evaluated individually to determine the volume (VHR) and fresh weight of their healthy fraction (FWHR) and the volume and fresh weight of clubroot (VCR and FWCR, respectively) (SANTOS et al., 2020). Total root volume and fresh weight (TRV and TRFW, respectively) were determined as the sum of the healthy fractions and clubroot. Based on these values, the percentage of roots with clubroot were calculated and expressed in volume (PVCR $=$ VCR.TRV $\left.^{-1} .100\right)$ and in fresh weight $($ PFWCR $=$ FWCR.TRFW ${ }^{-1}$.100).

Leaf, stem and roots samples were dried in an air circulation oven, at $65^{\circ} \mathrm{C}$, until reaching constant weight, to determine their respective dry weight. The cumulative plant dry weight (PDW) values were obtained as the sum of the dry weight of the respective organs. The dry weight of leaves produced from transplanting to collection were estimated considering the average dry weight of the sampled leaves and the number of leaf scars counted on the stem of the plants.

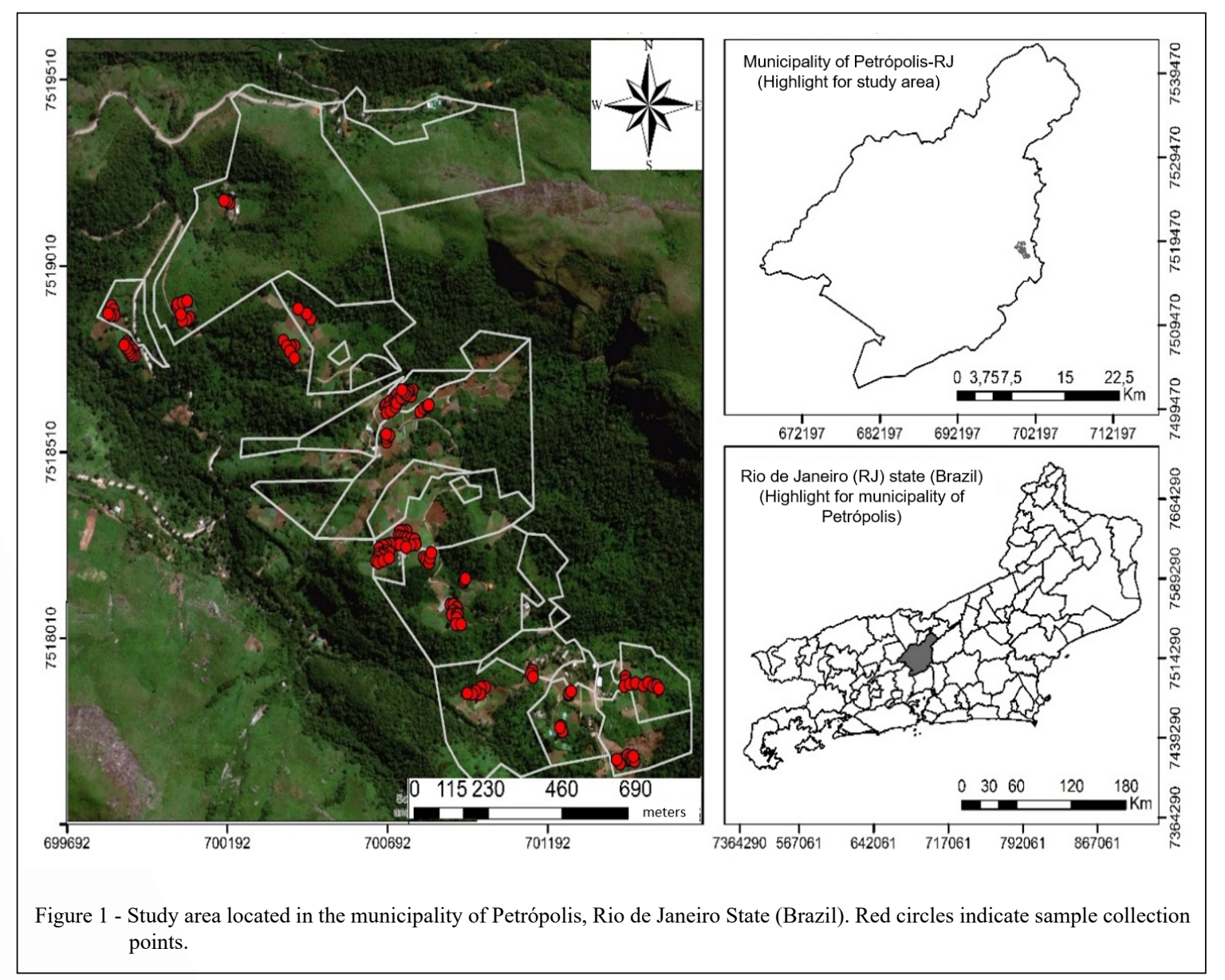

Ciência Rural, v.52, n.8, 2022. 
The dried plant samples were ground and used to determine the levels of $\mathrm{Ca}, \mathrm{Mg}, \mathrm{P}, \mathrm{K}$ and $\mathrm{Al}$ in the tissues. The samples were subjected to the process of open digestion in a digester block using nitric acid, following method 3050 (USEPA, 2008). The total Ca, $\mathrm{Mg}$ and $\mathrm{Al}$ contents were determined by inductively coupled plasma optical emission spectrophotometry (ICP-OES). The K content was determined by flame emission spectrophotometry and the P content by the metavanadate colorimetric method (SOUSA et al. 2020). The quality of the analyses was assessed using a certified sample of 1573a tomato leaves (NIST). Based on the levels reported in the roots, stems and leaves and in the dry mass, the cumulative values in the respective organs and in the plant (PL) were calculated.

The individual soil samples were prepared and analyzed according to DONAGEMMA et al. (2011), to determine the following variables: $\mathrm{pH}$ (in water); exchangeable $\mathrm{Ca}^{2+}, \mathrm{Mg}^{2+}$ and $\mathrm{Al}^{3+}\left(\mathrm{cmol}_{\mathrm{c}} \mathrm{dm}-\right.$ $\left.{ }^{3}\right) ; \mathrm{K}^{+}\left(\mathrm{mg} \mathrm{dm}^{-3}\right)$; assimilable $\mathrm{P}\left(\mathrm{mg} \mathrm{dm}^{-3}\right)$; potential acidity $\left(\mathrm{H}+\mathrm{Al}, \mathrm{cmol}_{\mathrm{c}} \mathrm{dm}^{-3}\right)$; cation-exchange capacity (CEC, $\mathrm{cmol}_{\mathrm{c}} \mathrm{dm}^{-3}$ ); base saturation (\%); and organic matter content $\left(\mathrm{OM}, \mathrm{g} \mathrm{kg}^{-1}\right)$.

\section{Data analysis}

A digital elevation and slope map of the areas was created with the georeferenced data from each collection point using ArcMap 10.1 software, from the ArcGis information system package. The topographic wetness index (TWI) was also determined using the SAGA 2.5 software.

Data on the occurrence of clubroot, soil fertility, relief, biomass accumulation and nutrient and $\mathrm{Al}$ content and accumulation in the plants were subjected to multivariate analysis. Principal component analysis (PCA), clustering, and crossvalidation were performed in discriminant analysis using R software (R Core Team, version 3.4.4). In PCA, to minimize the effect of autocorrelation, highly correlated variables were removed from the analysis.

The samples were grouped considering the soil fertility attributes. For this step, Euclidean distance was used as a measure of similarity and Ward's hierarchical method as a clustering algorithm. The number of optimal groups was determined considering 1.25 times the standard deviation of the linkage distance for all observations (BHERING et al., 2017). However, the result was subjected to cross-validation in discriminant analysis, to assess the general error rate of the sample distribution. The groups data were subjected to descriptive analysis (mean values, standard deviation, maximum and minimum), standardized considering mean 0 and variance 1 and plotted in a graph using Microsoft ${ }^{\circledR}$ Office Excel $^{\circledR}$ software.

\section{RESULTS AND DISCUSSION}

\section{Management of kale}

In the majority of the studied areas, kale and broccoli have been the predominant crops for over 20 years, with occasional rotation of other vegetables. Lettuce (Lactuca sativa L.) (38\%) and coriander (Coriandrum sativum L.) (24\%) were the vegetables most often cited as complementary crops or which preceded the studied kale crops. Additionally, in 14.3\% of the areas, the kale crop was preceded by kale itself or by broccoli, both of which are hosts to P. brassicae (Figure 2a). The successive cultivation of host species increases the inoculum potential and the occurrence of clubroot (HASSE et al., 2007; DIXON, 2009).

The time interval between the harvest of the last brassica in each area and the introduction of the new kale crop ranged from 6 months to 8 years, with an average of 2.5 years. In $100 \%$ of the cases, clubroot was cited as the main disease of kale or broccoli crops, followed by bacterial rot (Pectobacterium carotovorum subsp. carotovorum). This situation is directly related to the specialization of local farmers in producing Brassica, with reduced diversification or periods of rotation with other species. Plasmodiophora brassicae survives in soil as resisting spores that have a half-life of 3.6 years, but some spores may exist for at least 18 years (DIXON, 2009; DONALD \& PORTER, 2009). This problem is aggravated by the inadequate management of crop residues at the end of the kale cycle, whose incorporation includes roots with galls caused by the pathogen (74\%). The practice of plant uprooting, removal and exposure to the sun in an isolated area of the crop was reported in only 26\% of cases (Figure 2).

The specialization and frequent cultivation of Brassica in the same areas has ensured the survival of the pathogen in the studied areas. Coupled with this, practices that favor the dispersion of spores predominate, such as shared use of tractors and agricultural implements $(78.2 \%$ of the areas). In general, this equipment is not cleaned or sanitized after use, or before use in the subsequent area (52.94\%) (Figure 2b). The soil is prepared predominantly in favor of the slope, with the use of a plow or a rotary hoe and without the adoption of conservation practices, which benefits the erosion and dislodging of the pathogen resting spores. These conditions, along with irrigation commonly applied with sprinkler systems, favor erosive processes, loss of nutrients, 




and the dispersion of resting spores of $P$. brassicae by dislodging of soil and runoff of contaminated water (DONALD \& PORTER, 2009; GOSSEN et al., 2014; BHERING et al., 2017; SANTOS et al., 2021).

In addition to the survival and dispersion of pathogen resting spores, favored by the abovementioned practices, there was also a possible conductive effect of the chemical characteristics of the soils, which are related mainly to acidity and low levels of $\mathrm{Ca}^{2+}$. Although, liming was mentioned in most fields $(79 \%)$, this practice probably did not follow technical criteria, given the non-adoption of soil fertility analysis, reported in only $54 \%$ of cases (Figures 2c,d). When adopted, the limestone applications were performed by broadcasting followed by superficial incorporation into the soil with a rotary hoe. This period; however, varied from two days to three months before the kale seedlings were transplanted. When performed, soil liming in the areas preceded the collection of samples in this study two to 16 months.

Organic fertilization with poultry litter was adopted in $96 \%$ of the studied areas. In the vast majority of crops, this fertilization was applied in the furrows when the seedlings were transplanted (63.5\%) and, in $18.8 \%$ of the cases, it was also repeated as topdressing every two months. In $37.5 \%$ of the cases, poultry litter was applied only as topdressing (Figure 2e). The poultry litter rate used was estimated at 400 g plant ${ }^{-1}\left(26.6 \mathrm{Mg} \mathrm{ha}^{-1}\right)$.

In addition to fertilization with poultry litter in $96 \%$ of crops, fertilization with mineral 
sources of NPK was also reported in $96 \%$ of crops. In these situations, mineral fertilizers were applied in transplanting and as topdressing $(45.5 \%$ of the areas) or only as topdressing (54.5\% of the areas). Mineral fertilization at the time of transplanting is achieved with the application of about $10 \mathrm{~g} \mathrm{plant}^{-1}$ of a commercial formulation based on NPK (4-148 ) in the planting furrows. Topdressing applications followed the same pattern every 15-20 days, being performed at each time the leaves were harvested. In the remaining cases $(4.0 \%)$, fertilization was performed using castor seed cake or bokashi.

In each topdressing operation with organic or mineral sources, the practice of heaping by covering the plant stem base with soil is commonly performed, with the use of hoes.

\section{Occurrence of clubroot and general soil attributes}

The presence of plants with clubroot was identified in $75 \%$ of the fields and in $26.71 \%$ of the evaluated plants. The average severity of the disease, calculated based on the percentage volume of roots with clubroot (PVCR), ranged from $0 \%$ to $66.66 \%$, averaging $2.20 \%$. These values are lower than the average $66.0 \%$ recorded in cauliflower $(B$. oleracea var. botrytis) crops (BHERING et al., 2017), 45.0\% in Chinese cabbage (B. rapa ssp. pekinensis) (RUARO et al., 2010) and $80.0 \%$ in cabbage (B. oleracea var. capitata) (KOWATA-DRESCH \& MAY-DE MIO, 2012).

Despite reports of liming in most areas (Figure 2d), the soils in the respective areas were acidic (average $\mathrm{pH} 5.37$ ), with high potential acidity $\left(8.79 \mathrm{cmol}_{\mathrm{c}} \mathrm{dm}^{-3}\right)$ and low base saturation (mean $=$ $48.26 \%$ ) (Table 1). This result is probably due to the non-observance of technical criteria for calculating the doses of soil corrective, given the failure to perform fertility analysis (54.1\%) (Figure 2c). The date of liming, especially on seedling transplantation, also compromises the efficiency of the limestone reaction in the soil. In addition to being unsuitable for the cultivation of kale and other Brassica spp. species (FREIRE et al., 2013; TRANI et al., 2015; BHERING et al., 2017), these conditions favor clubroot (DIXON, 2009; RUARO et al., 2010; BHERING et al., 2017; BHERING et al., 2020).

The average assimilable $\mathrm{P}$ and exchangeable $\mathrm{K}$ levels recorded in the soil were very high (Table 1) (FREIRE et al., 2013). This result is probably related to the massive use of poultry litter and mineral fertilizers (BHERING et al., 2017; SOUSA et al., 2020) at random rates and frequency, that is, not based on soil fertility reports $(54.1 \%)$, as previously discussed.

In the leaves, the Ca contents ranged from 15.36 to $127.37 \mathrm{~g} \mathrm{~kg}^{-1}$ of dry weight, averaging of $51.53 \mathrm{~g} \mathrm{~kg}^{-1} ; \mathrm{Mg}$, between 3.61 and $16.60 \mathrm{~g} \mathrm{~kg}^{-1}$, averaging $8.55 \mathrm{~g} \mathrm{~kg}^{-1}$; and $\mathrm{K}$, from 23.60 to 87.76 $\mathrm{g} \mathrm{kg}^{-1}$, averaging $47.30 \mathrm{~g} \mathrm{~kg}^{-1}$. These values are considered high for the crop (TRANI et al., 2015), which is likely due to the high fertilizer rates applied and the management practices previously reported. $\mathrm{P}$ contents ranged from 4.46 to $13.93 \mathrm{~g} \mathrm{~kg}^{-1}$ and averaged $8.81 \mathrm{~g} \mathrm{~kg}^{-1}$. TRANI et al. (2015) considered the following macronutrient variations to be normal for kale: $\mathrm{Ca}=15$ to $25 \mathrm{~g} \mathrm{~kg}^{-1} ; \mathrm{Mg}=3$ to $7 \mathrm{~g} \mathrm{~kg}^{-1} ; \mathrm{P}=$ 20 to $40 \mathrm{~g} \mathrm{~kg}^{-1}$; and $\mathrm{K}=37 \mathrm{~g} \mathrm{~kg}^{-1}$.

\section{Clubroot intensity $\times$ soil attributes and relief}

The relationship between disease intensity and soil and relief attributes was demonstrated in

Table 1 - Mean, standard deviation (SD), and minimum and maximum values of $\mathrm{pH}$, exchangeable levels of $\mathrm{Ca}, \mathrm{Mg}, \mathrm{Al}$, and $\mathrm{K}$ in the soil, potential acidity $(\mathrm{H}+\mathrm{Al})$, cation-exchange capacity $(\mathrm{CEC})$, assimilable $\mathrm{P}$ content, base saturation $(\mathrm{V} \%)$ and organic matter (OM) referring to samples collected from 24 kale growing areas.

\begin{tabular}{|c|c|c|c|c|c|c|c|c|c|c|}
\hline & $\mathrm{pH}$ & $\mathrm{Ca}$ & $\mathrm{Mg}$ & $\mathrm{Al}$ & $\mathrm{H}+\mathrm{Al}$ & $\mathrm{CEC}$ & $\mathrm{K}$ & $\mathrm{P}$ & V & $\mathrm{OM}$ \\
\hline & (water) & \multicolumn{5}{|c|}{ 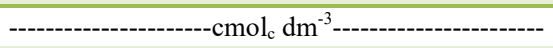 } & \multicolumn{2}{|c|}{----------mg dm ${ }^{-3}$------- } & \multicolumn{2}{|c|}{---------\%"-------- } \\
\hline Mean & 5.37 & 3.81 & 3.06 & 0.10 & 8.79 & 16.50 & 309.24 & 80.30 & 48.26 & 2.74 \\
\hline SD & 0.41 & 1.65 & 1.33 & 0.16 & 3.92 & 3.02 & 366.51 & 79.01 & 16.88 & 1.60 \\
\hline Minimum & 4.19 & 0.60 & 0.10 & 0.00 & 1.65 & 8.84 & 17.39 & 1.50 & 9.63 & 0.64 \\
\hline Maximum & 6.79 & 7.90 & 8.10 & 0.80 & 18.65 & 24.61 & $1,727.53$ & 483.51 & 81.34 & 6.50 \\
\hline Favorable to clubroot ${ }^{\mathrm{a}}$ & $<6.20$ & $<5.50$ & n.d. & n.d. & n.d. & n.d. & n.d. & n.d. & n.d. & n.d. \\
\hline Recommended for the kale ${ }^{b}$ & 6.50 & 3.00 & 0.90 & $<0.30$ & n.d. & n.d. & 135.00 & 30.00 & 80.00 & 3.44 \\
\hline
\end{tabular}

${ }^{a}$ Webster \& Dixon (1991); Dixon (2009); Donald \& Porter (2009); Ruaro et al. (2010); Bhering et al. (2017). ${ }^{\mathrm{b}}$ Freire et al. (2013); Trani et al. (2015). ${ }^{\text {n.d. }}$ Not defined. 
Principal component analysis (PCA). Components PC1 + PC2, calculated based on the percentage volume of clubroot in the roots (PVCR), topographic wetness index (TWI), $\mathrm{pH}$, organic matter contents $(\mathrm{OM})$, and $\mathrm{Ca}^{2+}$ and $\mathrm{Al}^{3+}$ contents, explained 53.14\% of the observed variations (Figure 3a). There was a direct and positive correlation between PVCR and TWI, which indicates drainage flow and a greater possibility of water accumulation and, possibly, $P$. brassicae resting spores accumulation. The percentage volume of clubroot in the roots was inversely related to the $\mathrm{pH}$ and exchangeable $\mathrm{Ca}$ and $\mathrm{OM}$ levels in the soil. These three attributes, in turn, were inversely related to the $\mathrm{Al}^{3+}$ levels in the soil (Figure 3a).

These results confirmed the strong relationship between disease intensity and the chemical characteristics of the soil, especially its acidity (Table 1) (WEBSTER \& DIXON, 1991; DIXON, 2009; DONALD \& PORTER, 2009; RUARO et al., 2010) and low $\mathrm{Ca}^{2+}$ levels $\left(3.81 \pm 1.6 \mathrm{cmolc} \mathrm{dm}^{-3}\right)$ (NIWA et al., 2008; BHERING et al., 2017; SANTOS et al., 2017; SANTOS et al., 2020). Higher soil moisture in areas with less slope, and more prone to water accumulation ( $>$ TWI), was also a factor that contributed to greater root infection by $P$. brassicae. Soil water films favor the mobility of zoospores (DIXON, 2009; GOSSEN et al., 2014). In addition, these points are also more prone to the accumulation of resting spores of $P$. brassicae, which are dislodged by the flood along with soil particles from crops located at the highest points of the landscape.

Components PC1 + PC2, which involved the relationships between the fresh weight of clubroot in the roots (FWCR) and the levels of macronutrients $(\mathrm{P}, \mathrm{K}, \mathrm{Ca}$ and $\mathrm{Mg}$ ) and $\mathrm{Al}$ in the roots, explained $57.08 \%$ of the observed variation (Figure $3 \mathrm{~b}$ ). In these, there was a close and positive relationship between FWCR and $\mathrm{Al}$ content in the roots (AlR), and an inverse relationship with the $\mathrm{P}, \mathrm{K}, \mathrm{Ca}$ and $\mathrm{Mg}$ contents in the roots (PR, KR, CaR, MgR, respectively) (Figure 3b). These results are possibly due to the favorable effect that a low $\mathrm{pH}$ has on the severity of clubroot and, simultaneously, on the higher solubility of toxic $\mathrm{Al}^{3+}$.

Soil acidity increases the solubility of $\mathrm{Al}^{3+}$, a common condition seen in soils in tropical regions, which usually have low $\mathrm{pH}$ and a high $\mathrm{Al}^{3+}$ content (FREIRE et al., 2013; BHERING et al., 2017; BOTERO et al., 2019; BHERING et al., 2020). This element has a phytotoxic effect on the roots (MEURER \& ANGHINONI, 2010) and has increased solubility in soils with $\mathrm{pH}<5.5$ (FREIRE et al., 2013; SANTOS et al., 2017; SANTOS et al., 2020). Under these conditions, it can inhibit cell division in the roots and compromise their elongation and growth, consequently reducing their water and nutrient absorption potential (CLUNE \& COPELAND, 1999;

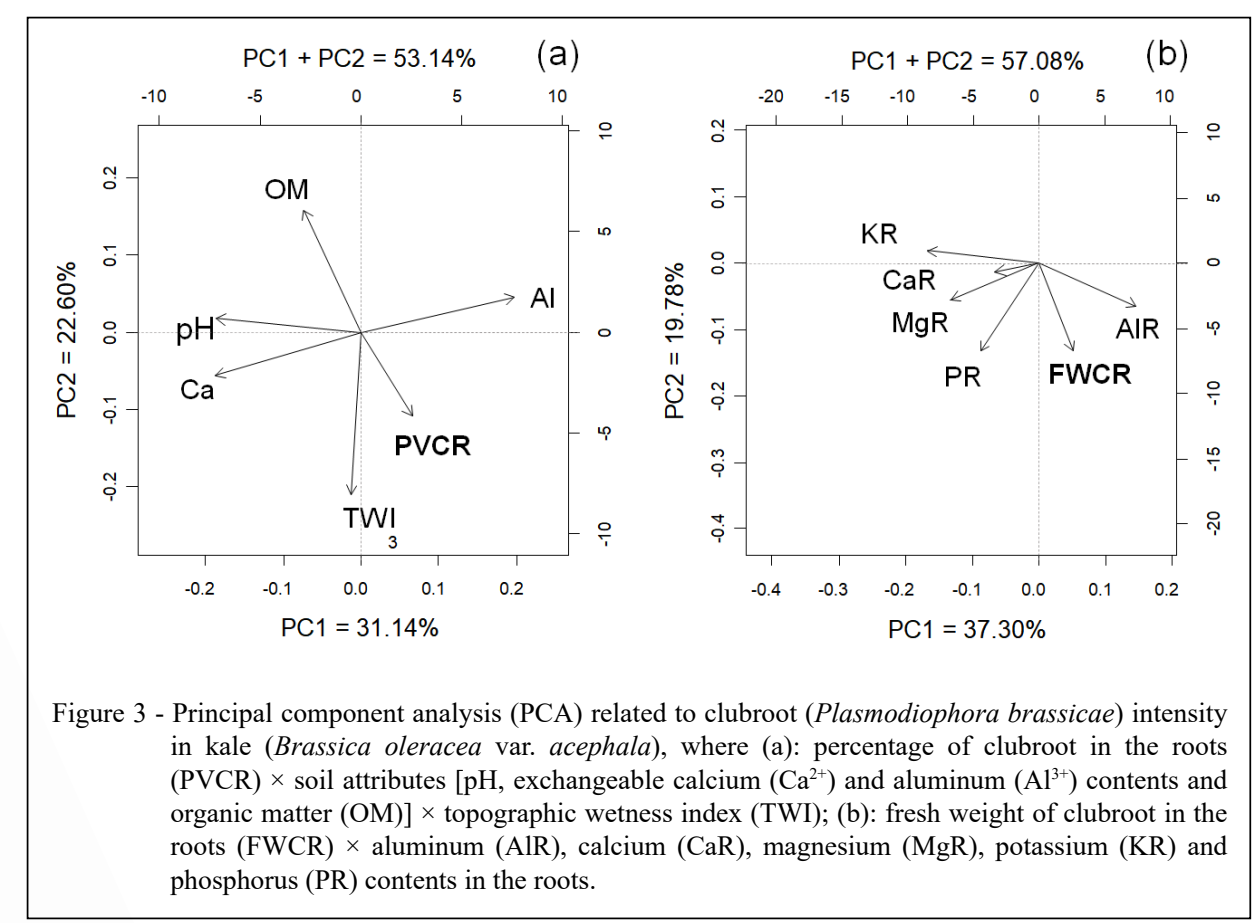

Ciência Rural, v.52, n.8, 2022. 
MEURER \& ANGHINONI, 2010). In addition to this deleterious effect of $\mathrm{Al}^{+3}$ on root development, a possible additive effect on the loss of active roots caused by $P$. brassicae is speculated (BHERING et al., 2017; BHERING et al., 2020).

Clubroot intensity, here expressed by the fresh weight of the galls (FWCR), was negatively related to the $\mathrm{K}(\mathrm{KR})$ and $\mathrm{P}(\mathrm{PR})$ contents in the roots and, positively, to the $\mathrm{Al}$ content (AlR) (Figure $3 \mathrm{~b}$ ). In the literature, high $\mathrm{K}$ concentrations have been associated with increased plant resistance to diseases (ZAMBOLIM \& VENTURA, 2012). High $\mathrm{K}$ and $\mathrm{P}$ concentrations could also lead to an increase in cell wall thickness, creating a mechanical barrier to the penetration of pathogens (ZAMBOLIM \& VENTURA, 2012). However, the interactions of these macronutrients with the establishment of P. brassicae in the roots of Brassica spp. are still unknown (DONALD \& PORTER, 2009).

Cluster analysis performed using soil fertility data from the samples resulted in the formation of 10 groups (Figure 4). Nevertheless, after cross-validation in discriminant analysis, we chose to divide the samples into three groups due to the lower overall error rate $(2.26 \%)$.

Group 1 (G1) allocated 110 samples; group 2 (G2), 18 samples; and group 3 (G3), 17 samples. These were represented by the standardized means, considering mean 0 and variance 1 (Figure 5). The three groups (G1, G2 and G3) showed different characteristics regarding disease intensity, soil fertility, relief, plant biomass accumulation, levels of $\mathrm{Ca}, \mathrm{Mg}, \mathrm{P}, \mathrm{K}$ and $\mathrm{Al}$ in the roots and accumulation of these elements in the plants.

Group 1 (G1) contained the samples of the most fertile soils (highest $\mathrm{pH}$; highest $\mathrm{Mg}^{2+}$, assimilable $\mathrm{P}$ and $\mathrm{OM}$ levels; lowest $\mathrm{Al}^{3+}$ and $\mathrm{H}+\mathrm{Al}$; and highest slope). This group also included the plants with the highest $\mathrm{K}$ content (KR), lowest $\mathrm{Al}$ content (AlR) and $\mathrm{Al}$ accumulation (AlAR) in the roots and the lowest percentage of galls caused by $P$. brassicae in the roots (PVCR) (Figure 5). The kale plants in this group had an average age of 5.7 months.

Group 2 (G2) consisted of the points with the greatest severity of clubroot, as expressed by PVCR, in addition to low-fertility soils (low $\mathrm{pH}$ and low $\mathrm{Mg}^{2+}$, assimilable $\mathrm{P}$ and $\mathrm{OM}$ levels), older plants (10.4 months), and relief position more prone to water accumulation, as expressed by TWI (Figure 5). The plants in this group also showed lower levels of $\mathrm{Mg}(\mathrm{MgR})$ and potassium $(\mathrm{KR})$ in the roots. The higher dry weight and nutrient accumulation values in the plants in this group are due to their longer time in the field (Figure 5).

Group 3 (G3) was composed of plants that exhibited high disease severity, which was close to that recorded in G2 despite their younger age (5.6 months) that was equivalent to that of the plants in G1. This result is due to the extremely favorable conditions to the disease, such as low pH (DIXON,

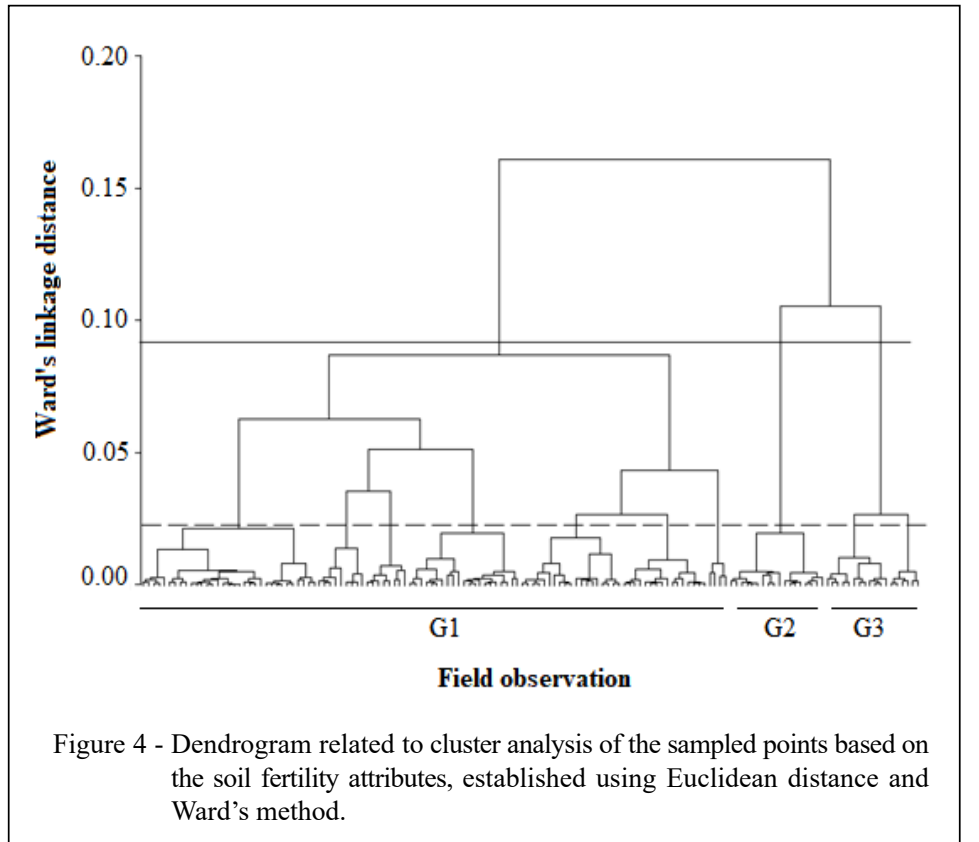

Ciência Rural, v.52, n.8, 2022. 


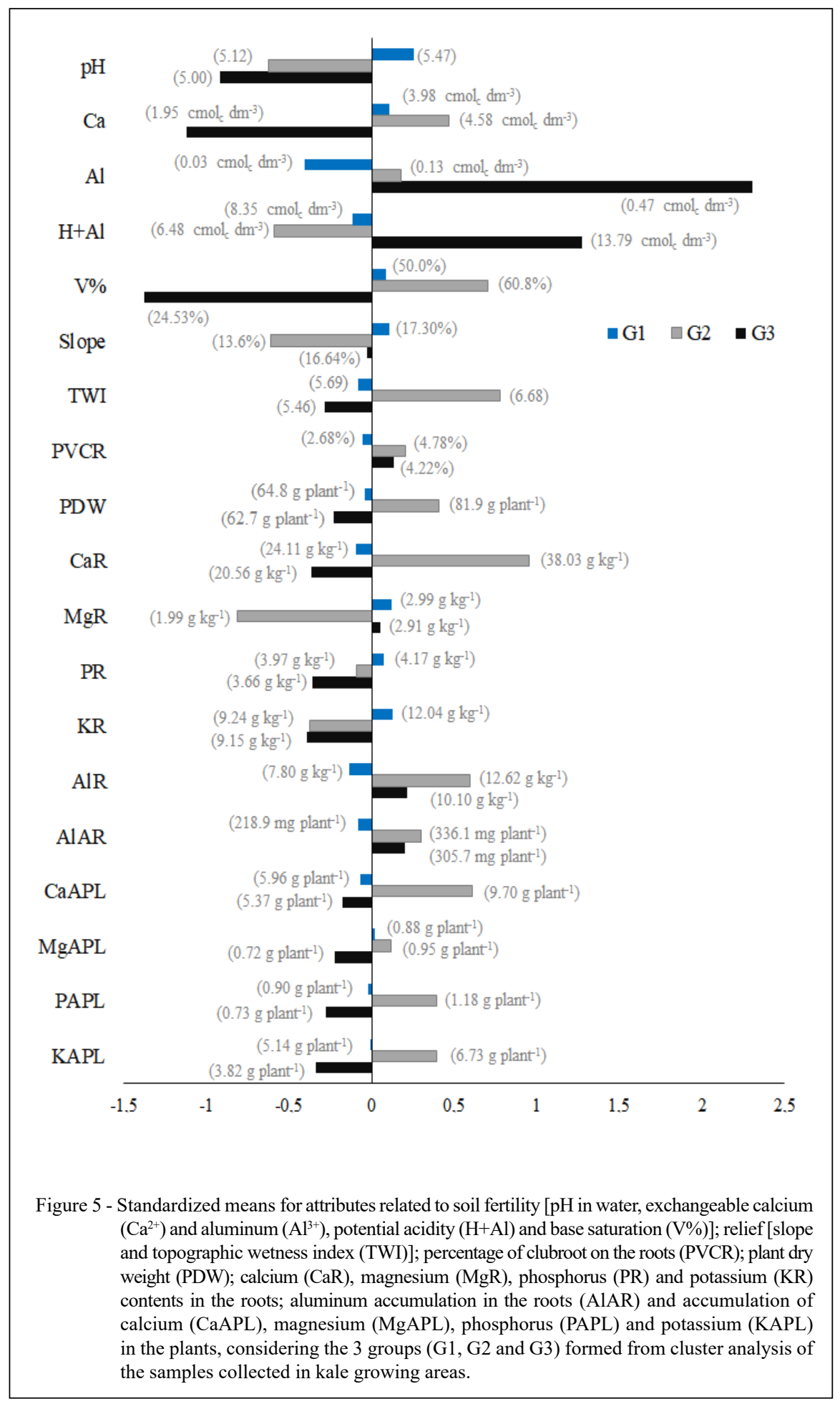

2009; RUARO et al., 2010; GOSSEN et al., 2014; BHERING et al., 2017), high potential acidity ( $\mathrm{H}+\mathrm{Al})$, high $\mathrm{Al}^{+3}$ levels in the soil and low fertility in general, in addition to high $\mathrm{Al}$ accumulation in the roots (Figure 5).
The close cultivation ages allow for direct comparisons to be made between groups G1 and G3. In these two groups, the values of soil chemical attributes and disease occurrence were 
clearly contrasting. Group 3 showed the lowest $\mathrm{pH}$, $\mathrm{Ca}^{2+}$ and base saturation values in the soil (Figure 5), the lowest biomass accumulation, low levels of macronutrients in the roots and lower accumulation of macronutrients in the plants (Figure 5). In this situation, the presence of a greater volume of roots with clubroot, as well as lower $\mathrm{pH}$ and high concentrations of $\mathrm{Al}^{3+}$, may have interfered with the absorption and accumulation of nutrients (BHERING et al., 2017).

The results of PCA and the characterization of the sample groups indicated a close relationship between $\mathrm{pH}$ and soil elements on the occurrence of clubroot in kale. The increase in disease severity was associated with soils with low pH (Figures 3 and 5). Moreover, similarly to the study by BHERING et al. (2017), high $\mathrm{Al}^{3+}$ values in the soil and the aluminum content and accumulation in the roots also showed a close and positive relationship with the severity of clubroot (Figures 3 and 5). These results thus signal the existence of possible interactions between $P$. brassicae and $\mathrm{Al}^{3+}$ that need to be evaluated in trials with controlled conditions.

The soils in the studied region were categorized as predominantly acidic (Table 1), favorable to the cycle of $P$. brassicae (DIXON, 2009; RUARO et al., 2010; GOSSEN et al., 2014; BHERING et al., 2017) and unfavorable to the cultivation of brassicas (Table 1) (FREIRE et al., 2013; TRANI et al., 2015; SANTOS et al., 2020). The soil and crop management commonly adopted in the region and little attention to chemical analysis and soil acidity correction may be potentiating the losses caused by the disease (Figure 2).

At first, the management of clubroot in kale crops in tropical areas of mountain agriculture is more complex than for other brassicas. Kale is a longer-cycle crop that reaches up to 12 months in the field (TRANI et al., 2015). Under these conditions, the initial non-correction of soil acidity during the establishment of the crop extends throughout the cycle and can hardly be adjusted in the subsequent months until its end.

Limestone application in the soil requires homogenization and an adequate period for the complete reaction of the corrective. In general, this period must be equal to or greater than three months, depending on soil characteristics, moisture and type of corrective used (FREIRE et al., 2013; SANTOS et al., 2017). In sloping conditions, adequate correction of soil acidity is difficult (SANTOS et al., 2020). In such conditions, previous application ( $\geq 3$ months) of homogenized limestone may be recommended in future planting furrows, which will have similar effects to broadcast application throughout the area (SANTOS et al., 2020), in addition to the use of more reactive soil amendments.

Unlike other botanical varieties of $B$. oleracea such as cauliflower and broccoli, kale is propagated predominantly by shoots from leaf axillary buds (TRANI et al., 2015). In each topdressing operation, a heap of soil is frequently placed at the base of the stem. This practice stimulates the emergence of adventitious roots, which can probably compensate for the loss of roots by clubroot and favor plant longevity.

The chemical characteristics of the soil, sloping relief, elevated dispersion of $P$. brassicae resting spores, and recurrent flaws in crop management have negatively affected kale production in the region. These adversities are likely being offset by the massive application of poultry litter and mineral fertilizers and, probably, by the continuous heaping and renewal of roots.

\section{CONCLUSION}

Clubroot is present in $75 \%$ of the kale crops in the studied region.

Crop specialization, crop residue incorporation, reduced rotation periods with nonhosts, low adoption of soil analysis and liming, sharing of tractors and implements, as well as management that favors erosion processes contribute to the increasing spread and occurrence of the disease in the region.

The local conditions of sloping relief, acidic soils, soils with a high $\mathrm{Al}^{3+}$ content and areas more prone to water accumulation favor the occurrence of clubroot in kale plants grown in mountain agriculture areas under tropical conditions.

Among the practices suggested for reversing the losses caused are the removal of crop residues, cleaning of machinery and implements for each use, adoption of conservation practices, greater diversification and longer crop rotation with non-host species and rational management of soil fertility with emphasis on acidity correction.

\section{ACKNOWLEDGEMENTS}

The authors would like to thank the 'Fundação Carlos Chagas Filho de Amparo a Pesquisa do Estado do Rio de Janeiro FAPERJ,' the 'Conselho Nacional de Desenvolvimento Científico e Tecnológico - CNPq', and the 'Coordenação de Aperfeiçoamento de Pessoal de Nível Superior - CAPES, - Finance Code 001' for their financial support. 


\section{DECLARATION OF CONFLICT OF INTEREST}

We have no conflict of interest to declare.

\section{AUTHORS' CONTRIBUTIONS}

All authors contributed equally for the conception and writing of the manuscript. All authors critically revised the manuscript and approved of the final version.

\section{REFERENCES}

BHERING, A. S. et al. Soil factors related to the severity of Clubroot in Rio de Janeiro, Brazil. Plant Disease, v.101, n.8, p.1345-1353. 2017. Available from: <https://doi.org/10.1094/ PDIS-07-16-1024-SR>. Accessed: May, 22, 2020. doi: 10.1094/ PDIS-07-16-1024-SR.

BHERING, A. S. et al. Soil management in a mountain agroecosystem and clubroot disease. Plant Pathology, v.69, n.2, p.302-309, 2020. Available from: <https://doi.org/10.1111/ ppa.13123>. Accessed: Nov. 18, 2020. doi: 10.1111/ppa.13123.

BOTERO, A. et al. Clubroot disease in Latin America: distribution and management strategies. Plant Pathology, v.68, n.5, p.827833, 2019. Available from: <https://doi.org/10.1111/ppa.13013>. Accessed: Jul. 13, 2020. doi: 10.1111/ppa.13013.

CLUNE, T. S.; COPELAND, L. Effects of aluminium on canola roots. Plant and Soil, v.216, n.1, p.27-33, 1999. Available from: $<$ https://doi.org/10.1023/A:1004789014255>. Accessed: May, 20, 2020. doi: 10.1023/A:1004789014255.

DIXON, G. R. Plasmodiophora brassicae in its environment Journal of Plant Growth Regulation, v.28, n.3, p.212-228, 2009. Available from: < https://doi.org/10.1007/s00344-0099098-3>. Accessed: May, 20, 2020. doi: 10.1007/s00344-0099098-3.

DONAGEMMA, G. K. et al. Manual de métodos de análises de solos. Rio de Janeiro: Embrapa Solos, 2011. 230p.

DONALD, C.; PORTER, I. Integrated control of clubroot. Journal of Plant Growth Regulation, v.28, n.3, p.289-303, 2009. Available from: $<$ https://doi.org/10.1007/s00344-009-90947>. Accessed: May, 20, 2020. doi: 10.1007/s00344-009-9094-7.

GOSSEN, B. D. et al. Effect of environmental parameters on clubroot development and the risk of pathogen spread. Canadian Journal of Plant Pathology, v.36, n.1, p.3748, 2014. Available from: <https://doi.org/10.1080 /07060661.2013.859635>. Accessed: May, 13, 2020. doi: 10.1080/07060661.2013.859635.

FREIRE, L. R. et al. Manual de calagem e adubação do Estado do Rio de Janeiro. Seropédica: Editora Universidade Rural, 2013. 430p.

HASSE, I. et al. Efeito do pré-plantio com plantas medicinais e aromáticas no controle de Plasmodiophora brassicae. Summa Phytopathologica, v.33, n.1, p.74-79, 2007. Available from: $<$ https://doi.org/10.1590/S0100-54052007000100011>. Accessed: Jun. 5, 2021. doi: 10.1590/S0100-54052007000100011.
KOWATA-DRESCH, L. S.; MAY-DE MIO, L. L. Clubroot management of highly infested soils. Crop Protection, v.35, p.47-52, 2012. Available from: <https://doi.org/10.1016/j. cropro.2011.12.012>. Accessed: Jun. 5, 2021. doi: 10.1016/j. cropro.2011.12.012

MEURER, E. J., ANGHINONI, I. A solução do solo. In: MEURER, E. J. Fundamentos de Química do Solo. Porto Alegre: Evangraf, 2012. Chapter.4, p.87-113.

NIWA, R. et al. Suppression of clubroot disease under neutral $\mathrm{pH}$ caused by inhibition of spore germination of Plasmodiophora brassicae in the rhizosphere. Plant Pathology, v.57, n.3, p.445-452, 2008. Available from: <https://doi.org/10.1111 /j.1365-3059.2007.01817.x>. Accessed: May, 20, 2020. doi: 10.1111/j.1365-3059.2007.01817.x.

RUARO, L. et al. Efeito do $\mathrm{pH}$ do solo em diferentes níveis de concentração de inóculo no controle de Plasmodiophora brassicae. Summa Phytopathologica, v.36, n.1, p.1620, 2010. Available from: <https://doi.org/10.1590/S010054052010000100002>. Accessed: Jun. 5, 2021. doi: 10.1590/ S0100-54052010000100002.

SAMEC, D. et al. Kale (Brassica oleracea var. acephala) as a superfood: review of the scientific evidence behind the statement. Critical Reviews in Food Science and Nutrition, v.59, n.15, p.2411-2422, 2019. Available from: <https://doi.org/1 0.1080/10408398.2018.1454400>. Accessed: Feb. 12, 2020. doi: $10.1080 / 10408398.2018 .1454400$

SANTOS, C. A. et al. Liming and biofungicide for the control of clubroot in cauliflower. Pesquisa Agropecuária Tropical, v.47, n.3, p.303-311, 2017. Available from: <https://doi. org/10.1590/1983-40632016v4746936>. Accessed: Feb. 10, 2020. doi: 10.1590/1983-40632016v4746936.

SANTOS, C. A. et al. Use of limestone and agricultural gypsum in cauliflower crop management and clubroot control in mountain farming. Acta Scientiarum Agronomy, v.42, e42494, 2020. Available from: <https://doi.org/10.4025/actasciagron. v42i1.42494>. Accessed: Feb. 10, 2020. doi: 10.4025/actasciagron. v42i1.42494.

SANTOS, C. A. et al. Recomendações de manejo visando o controle da hérnia das crucíferas Informe Técnico, v.1, n.2, 1-20, 2021. Available from: <https://doi.org/10.29327/837780.1-2>. Accessed: Jun. 5, 2021. doi: 10.29327/837780.1-2.

SOUSA, F. F. et al. Lead and cadmium transfer factors and the contamination of tomato fruits (Solanum lycopersicum) in a tropical mountain agroecosystem. Bulletin of Environmental Contamination and Toxicology, v.105, p.325-331, 2020. Available from: <https://doi.org/10.1007/s00128-020-02930-w >. Accessed: Dec. 20, 2020. doi: 10.1007/s00128-020-02930-w.

TRANI, P. E. et al. Couve de folha: do plantio à pós-colheita. Campinas: Instituto Agronômico, 2015. 36p.

USEPA - United States Environmental Protection Agency. Method 3050: Acid digestion of sediments, sludges, and soils. 2008. Available from: <http://www.epa.gov/waste/hazard/testmethods>. Accessed: Feb. 15, 2018.

VIÉGAS, A. P.; TEIXEIRA, A. R. Alguns fungos do Brasil (Phycomycetos). Bragantia, v.3, n.8, p.223-245, 
1943. Available from: <https://doi.org/10.1590/S0006$87051943000800003>$. Accessed: Feb. 15, 2020. doi: 10.1590/ S0006-87051943000800003.

WEBSTER, M. A.; DIXON, G. R. Calcium, pH and inoculum concentration influencing colonization by Plasmodiophora brassicae. Mycological Research, v.95, n.1, p.64-73, 1991.
Available from: <https://doi.org/10.1016/S0953-7562(09)81362-2>. Accessed: Feb. 12, 2020. doi: 10.1016/S0953-7562(09)81362-2.

ZAMBOLIM, L.; VENTURA, J. A. Efeito do nitrogênio na interação com doenças de plantas. In: ZAMBOLIM, L.; VENTURA, J. A. Efeito da nutrição mineral no controle de doenças de plantas. Viçosa: UFV, 2012. Chapter. 3, p.47-80. 